\title{
Soft tissue tension in extension in total knee arthroplasty affects postoperative knee extension and stability
}

Hiroshi Asano - Takeshi Muneta - Ichiro Sekiya

Published online: 14 March 2009

(C) Springer-Verlag 2009

Erratum to: Knee Surg Sports Traumatol Arthrosc

(2008) 16:999-1003

DOI 10.1007/s00167-008-0591-1

Unfortunately, we had indicated the incorrect affiliation for the corresponding author. It should have been Tokyo Medical and Dental University as now given below.

The online version of the original article can be found under doi:10.1007/s00167-008-0591-1.

H. Asano $(\bowtie) \cdot$ T. Muneta $\cdot$ I. Sekiya Department of Orthopaedic Surgery,

Tokyo Medical and Dental University,

Yushima 1-5-45, Bunkyouku, Tokyo, Japan

e-mail: h-asano@mtg.biglobe.ne.jp 